\title{
Effects of paclobutrazol on ethylene sensitivity of potted pepper cultivars
}

\author{
Efeitos do paclobutrazol na sensibilidade ao etileno de cultivares de pimenta em vaso \\ Efectos del paclobutrazol sobre la sensibilidad al etileno de cultivares de pimiento en maceta
}

Received: 12/30/2022 | Reviewed: 01/07/2022 | Accept: 01/15/2022 | Published: 01/17/2022

Mayana Ferreira Nascimento
ORCID: https://orcid.org/0000-0002-9844-0594
Universidade Federal do Piauí, Brasil
E-mail: mayana.f.nascimento@ gmail.com
Fernanda Ferreira de Araújo
ORCID: https://orcid.org/0000-0001-7420-9614
Universidade Federal de Viçosa, Brasil
E-mail: fernandaufv@ hotmail.com
Rusthon Magno Cortez dos Santos
ORCID: https://orcid.org/0000-0002-6967-2871
Universidade Federal de Viçosa, Brasil
E-mail: rusthoncortez@hotmail.com
João José da Silva Neto
ORCID: https://orcid.org/0000-0002-8094-9982
E-mail: joaoneto.agro@ domail.com
Claudio Horst Bruckner
Instituto Federal de Educação, Ciência e Tecnologia do Mato Grosso Sul, Brasil
ORCID: https://orcid.org/0000-0002-6249-3686
Universidade Federal de Viçosa, Brasil
E-mail: claudio.bruckner@gmail.com
Fernando Luiz Finger
ORCID: https://orcid.org/0000-0002-4046-9634
Universidade Federal de Viçosa, Brasil
E-mail: ffinger@ufv.br

\begin{abstract}
Exposure to ethylene of ornamental plants is one of the factors that affect the life cycle post-production of these plants. The aim of this work was to evaluate the effects of paclobutrazol (PBZ) on the ethylene related responses of ten pepper cultivars of the genus Capsicum and one Solanum by simulating transport and commercialization. The cultivars were treated with PBZ at concentrations of $0,5,10$ and $20 \mathrm{mg} \mathrm{L}^{-1}$ applied on the potted cultivation substrate. When the plants had $30 \%$ of ripe fruits, they were transferred to a $90 \mathrm{~L}$ sealed container and treated with $10 \mu \mathrm{L} \mathrm{L}^{-1}$ ethylene for 48 hours and then kept at room temperature. Percentages of leaf (LA) and fruit abscission (FA) the plants were recorded at every two days (48h, 96h and $144 \mathrm{~h})$. The design used was completely randomized, in an $11 \mathrm{x} 4$ factorial scheme. The PBZ did not completely inhibit the deleterious effects of exogenous ethylene on plants. However, the 'Pérola Negra' showed moderate sensitivity for leaf and fruit abscission, and the 'Bode Vermelha' for leaf abscission at a concentration of $10 \mathrm{mg} \mathrm{L}^{-1}$. PBZ prevented partially the abscission of fruits of the 'Pirâmide Ornamental' pepper at rates of 5 and $10 \mathrm{mg} \mathrm{L}^{-1}$, and 'Tabasco' pepper at a concentration of $10 \mathrm{mg} \mathrm{L}^{-1}$. In addition, cultivars showed darker foliage when treated with PBZ.
\end{abstract}

Keywords: Ethylene inhibitors; Ornamentation; Commercialization; Post-production.

\section{Resumo}

A exposição ao etileno de plantas ornamentais é um dos fatores que afetam o ciclo de vida pós-produção destas plantas. O objetivo do estudo foi avaliar os efeitos do paclobutrazol (PBZ) sobre a sensibilidade ao etileno de dez cultivares de pimenta do genêro Capsicum e uma Solanum, em simulação de transporte ou comercialização. As cultivares foram tratadas com PBZ nas concentrações $0,5,10$ e $20 \mathrm{mg} \mathrm{L}^{-1}$ sobre o substrato de cultivo em vaso. Quando as plantas apresentaram 30\% dos frutos maduros, foram transferidas para um recipiente vedado de $90 \mathrm{~L}$ e tratados com etileno à $10 \mu \mathrm{L} \mathrm{L}^{-1}$ por 48 horas, em seguida, mantidas à temperatura ambiente. As porcentagens de folhas (LA) e abscisão de frutos (AF) das plantas foram registradas a cada dois dias (48, 96 e 144h). O delineamento utilizado foi inteiramente casualizado, em esquema fatorial 11 x 4. O PBZ não inibiu totalmente os efeitos deletérios do etileno exógeno nas plantas. Porém, a 'Pérola Negra' apresentou sensibilidade moderada para abscisão de folhas e frutos, e a 'Bode vermelha' para abscisão foliar na concentração $10 \mathrm{mg} \mathrm{L}^{-1}$. De forma moderada, o PBZ impediu a abscisão de frutos da 'Pirâmide ornamental' nas doses 5 e $10 \mathrm{mg} \mathrm{L}^{-1}$, e da pimenta 'Tabasco' na concentração $10 \mathrm{mg}$ $\mathrm{L}^{-1}$. Além disso, os cultivares apresentaram folhagens mais escuras quando tratadas com PBZ.

Palavras-chave: Inibidor do etileno; Ornamentação; Comercialização; Pós-produção. 


\section{Resumen}

La exposición al etileno de las plantas ornamentales es uno de los factores que afectan el ciclo de vida posproducción de estas plantas. El objetivo de este estudio fue evaluar los efectos del paclobutrazol (PBZ) sobre la sensibilidad al etileno de diez cultivares de pimiento del género Capsicum y un Solanum, en simulación de transporte o comercialización. Los cultivares de pimiento con PBZ a concentraciones de $0,5,10$ y $20 \mathrm{mg} \mathrm{L}^{-1}$ sobre el sustrato de cultivo en maceta. Cuando las plantas tenían $30 \%$ de frutos maduros, se transfirieron a un recipiente sellado de $90 \mathrm{~L}$ y se trataron con etileno a $10 \mu \mathrm{L} \mathrm{L}^{-1}$ durante 48 horas, luego se mantuvieron a temperatura ambiente. Los porcentajes de abscisión de hojas (LA) y frutos (AF) de las plantas se registraron cada dos días (48, 96 y 144h) después del tratamiento con etileno. El diseño experimental fue completamente al azar, en un esquema factorial de 11 x 4 . El PBZ no inhibió completamente los efectos deletéreos del etileno exógeno en las plantas. Sin embargo, la 'Pérola Negra' mostró una sensibilidad moderada para la abscisión de hojas y frutos y la 'Bode vermelha' para la abscisión de hojas a una concentración de $10 \mathrm{mg} \mathrm{L}{ }^{-1}$. Moderadamente, PBZ impidió la abscisión de frutos de pimiento 'Pirâmide ornamental' a dosis de 5 y $10 \mathrm{mg} \mathrm{L}^{-1}$, y pimiento 'Tabasco' a una concentración de $10 \mathrm{mg} \mathrm{L}^{-1}$. Además, los cultivares mostraron un follaje más oscuro cuando se trataron con PBZ.

Palabras clave: Inhibidor de etileno; Ornamentación; Comercialización; Postproducción.

\section{Introduction}

Peppers (Capsicum ssp.) are among the most important vegetables of the Solanaceae family (Mahmoud \& ElEslamboy, 2015; Costa et al., 2021). The genetic diversity of the Capsicum genus includes plants with different sizes, types, colors, flavor and heat of the fruits (Pinto, Santos, Araújo \& Silva, 2016). Peppers fruits are important part of the spice industry (Rebouças, Valverde \& Teixeira, 2013), being consumed in natura, processed in the form of sauce, jams, jellies and paprika. In addition, peppers are an important source of antioxidant substances, including vitamin C, carotenoids and vitamin $\mathrm{E}$ (Finger \& Pereira, 2016).

Peppers plants have been gaining market as ornamentals. In the international market, as in the United States and some countries in Europe, ornamental peppers have great prominence and good acceptance by the consumer (Bosland, 1999). In Brazil, the sale of ornamental pepper plants is still restricted to open markets and some supermarkets, but this reality is changing, and consumers are already buying peppers in flower shops (Rêgo, Rêgo \& Barroso, 2016). The varied foliage, intensity in the color of its fruits contrasting with the foliage, ease of seed propagation, shorter harvest time, tolerance to heat and drought and high post-production quality are striking characteristics of ornamental peppers (Stommel \& Bosland, 2006 ; Rêgo \& Rêgo, 2016 and 2018).

Ornamental peppers are exposed to stresses during their transport to their final destination that can affect their ornamental quality and shelf life (Lima, Ribeiro, Oliveira, Costa \& Finger, 2017; França et al., 2018). Transport conditions in Brazil are precarious, ornamental plants are transported in dark trucks, without ventilation and limitid supply of water for more than 48 hours, with accumulation and exposure of the plants to ethylene present in the air inside the trucks (Iqbal et al., 2017). Ethylene is a plant hormone produced in low concentrations by the plants, regulating plant growth and development, flowering, fruit maturation and senescence processes (Chen, Etheridge \& Schaller, 2005; Santos et al., 2013). However, exposure to high concentrations of ethylene can cause undesirable effects on the plant, such as abscission of leaves, flowers and fruits in different degrees and chlorophyll degradation (Lima et al., 2017; Nascimento et al., 2018; Ribeiro et al., 2019a). The effects caused by ethylene will depend on the ethylene concentration, exposure time, temperature, development stage and sensitivity of the species or variety (Xin et al., 2019).

Treatments with inhibitors of ethylene synthesis and action are indicated to delay the harmful effects of the hormone. Several authors describe the action of paclobutrazol (PBZ) in inhibiting ethylene synthesis in plants (Min \& Bartholomew, 1996; Antunes, Ono \& Sampaio, 2008; Ahmad, Dole \& Whipker, 2015). PBZ is a regulator that blocks the biosynthesis of gibberellic acid, inhibiting plant growth and increasing chlorophyll in ornamental pepper leaves (França et al., 2017).

Few studies were carried out in ornamental peppers in relation to post-production factors, the levels of sensitivity to ethylene, 
and the action of inhibitor on post-production longevity of potted plants. Therefore, the aim of the study was to evaluate the effects of different concentrations of the growth regulator paclobutrazol on the post-production shelf life of ten pepper cultivars of Capsicum and one Solanum.

\section{Methodology}

\subsection{Conducting the experiment}

The experiment was conducted in a greenhouse at the Department of Agronomy of the Federal University of Viçosa $\left(20^{\circ} 45^{\text {ce }} 47^{\prime \prime} \mathrm{LS}\right.$ and $\left.42^{\circ} 49^{\circ e} 13^{\prime \prime} \mathrm{LW}\right)$. The treatments consisted of ten commercial pepper cultivars of the genus Capsicum: ¿Pérola negra' and 'Jalapeño' (Capsicum annuum); 'Malagueta', 'Tabasco', 'Strombolli ornamental', 'Pirâmide ornamental' (Capsicum frutescens); 'Rocoto vermelha' (Capsicum pubescens); 'Dedo de moça' (Capsicum baccatum), 'Bode vermelha' and 'Biquinho vermelha' (Capsicum chinense), and a Solanum: 'Peloteira' (Solanum pseudocapsicum).

Seeding was carried out in 200 cell polystyrene trays containing commercial substrate. When the plantlets had four pairs of leaves, one plant was transplanted to $700 \mathrm{ml}$ pots, number $13(10 \mathrm{~cm}$ in height $\times 9 \mathrm{~cm}$ in bottom diameter $\times 12 \mathrm{~cm}$ in top diameter). The growth regulator, paclobutrazol (PBZ) was applied after the plants had a height between 10 and $15 \mathrm{~cm}$. Each pot received $150 \mathrm{~mL}$ of the PBZ solution drenched directly in the substrate at concentrations of $0.5,10$ and $20 \mathrm{mg} \mathrm{L}^{-1}$, corresponding to $0.75,1.5$ and $3 \mathrm{mg}$ of the active principle ( $250 \mathrm{~g}$ ai PBZ per liter, Syngenta Crop Protection), similar to that described by França et al., (2018).

\subsection{Ethylene treatment}

When plants reached the stage of $30 \%$ of full ripe mature fruits, plants were evaluated for sensitivity to ethylene according to Segatto, Finger, Barbosa, Rêgo e Pinto (2013). Pots were placed in 90-liter sealed chambers in the dark simulating stress conditions during transport or storage, and then exposed to $10 \mu \mathrm{L} \mathrm{L}^{-1}$ of ethylene for 48 hours.

After exposure to ethylene, the pots were transferred to a room simulating the interior conditions of stores, supermarkets and homes of the final consumers at $25 \pm 1{ }^{\circ} \mathrm{C}, 8-10 \mu \mathrm{mol} \mathrm{s}-1 \mathrm{~m}-2$ of white fluorescent light, and RH $60-65 \%$ and watered when necessary. Percentages of leaf (LA) and fruit abscission (FA) the plants were recorded at every two days (48h, 96h and 144h).

\subsection{Statistical analysis}

The experimental design used was completely randomized, in a factorial scheme $11 \times 4$, eleven genotypes and four doses of PBZ, with five replications. Quantitative data were subjected to analysis of variance, with subsequent grouping of means by the Skott-Knott criterion at $1 \%$ probability and comparison of means by the Dunnett test at $5 \%$. Statistical analyzes were performed using the Genes computer program (Cruz, 2013).

\section{Results and Discussion}

The effects of the interaction between dose and genotypes were significant by the $F$ test $(p<0.01)$ for leaf and fruit abscission (data not shown), reflecting the behavior of cultivars for resistance to ethylene when treated with different rates of paclobutrazol (PBZ).

Table 1 shows the average of pepper cultivars, treated with PBZ for leaf abscission and fruit abscission after 48 hours of exposure to ethylene. Plants treated with 5,10 and $20 \mathrm{mg} \mathrm{L}^{-1}$ of PBZ were divided into two groups according to leaf abscission. The cultivars 'Jalapeño', 'Biquinho Vermelha', 'Tabasco' and 'Rocoto Vermelha' formed a group with greater leaf 
abscission, above 50\% (Table 1), making them unfeasible for commercialization. For these cultivars, PBZ was not effective in reducing sensitivity to ethylene. It is important for every segment of the production chain (production, distribution and commercialization) to discover methods or hormones that reduce the negative effects caused by ethylene, not only in ornamental peppers, but also in every sector of flowers and ornamental plants that depend on trucks to be delivered to the final destination, large commercial centers, supermarkets and open markets in the cities.

Table 1 - Means of eleven cultivars for leaf abscission (LA) and pepper fruit abscission (FA), 48 hours after exposure to ethylene, with application of 0,5, 10 and $20 \mathrm{mg} \mathrm{L}^{-1}$ of PBZ. Equal letters in columns do not differ statistically by Scott-Knott criterion at $1 \%$ probability. $*$ followed on the same line indicates significance by the Dunnett test at $5 \%$ probability.

\begin{tabular}{|c|c|c|c|c|c|c|c|c|}
\hline \multirow{3}{*}{ Cultivars } & \multicolumn{8}{|c|}{48 hours } \\
\hline & \multicolumn{2}{|c|}{$0 \mathrm{mg} \mathrm{L}^{-1}$} & \multicolumn{2}{|c|}{$5 \mathrm{mg} \mathrm{L}^{-1}$} & \multicolumn{2}{|c|}{$10 \mathrm{mg} \mathrm{L}^{-1}$} & \multicolumn{2}{|c|}{$20 \mathrm{mg} \mathrm{L}^{-1}$} \\
\hline & LA & FA & LA & FA & LA & FA & LA & FA \\
\hline Pirâmide ornamental & $41.69 \mathrm{~b}$ & $54.67 \mathrm{a}$ & $43.58 \mathrm{~b}^{\mathrm{ns}}$ & $21.14 \mathrm{a}^{\mathrm{ns}}$ & $43.53 b^{\mathrm{ns}}$ & $26.44 \mathrm{~b}^{\mathrm{ns}}$ & $45.92 b^{\mathrm{ns}}$ & $18.29 b^{*}$ \\
\hline Pérola negra & 68.97 & $33.01 \mathrm{a}$ & $16.90 b^{*}$ & $5.83 \mathrm{a}^{\mathrm{ns}}$ & $23.59 \mathrm{~b} *$ & $9.91 b^{\mathrm{ns}}$ & $27.76 b^{*}$ & $26.32 \mathrm{~b}^{\mathrm{ns}}$ \\
\hline Dedo de moça & $52.78 \mathrm{~b}$ & $31.27 \mathrm{a}$ & $34.38 \mathrm{~b}^{\mathrm{ns}}$ & $31.33 \mathrm{a}^{\mathrm{ns}}$ & $20.97 \mathrm{~b}^{\mathrm{ns}}$ & $7.93 b^{\mathrm{ns}}$ & $28.32 \mathrm{~b}^{\mathrm{ns}}$ & $2.85 b^{\mathrm{ns}}$ \\
\hline Bode vermelha & $38.91 \mathrm{~b}$ & $38.11 \mathrm{a}$ & $37.37 \mathrm{~b}^{\mathrm{ns}}$ & $45.25 \mathrm{a}^{\mathrm{ns}}$ & $20.21 \mathrm{~b}^{\mathrm{ns}}$ & $57.80 \mathrm{a}^{\mathrm{ns}}$ & $26.53 \mathrm{~b}^{\mathrm{ns}}$ & $54.17 \mathrm{a}^{\mathrm{ns}}$ \\
\hline Peloteira & $5.88 \mathrm{c}$ & $6.04 \mathrm{~b}$ & $39.58 b^{*}$ & $21.74 \mathrm{a}^{\mathrm{ns}}$ & $29.27 \mathrm{~b}^{\mathrm{ns}}$ & $15.53 \mathrm{~b}^{\mathrm{ns}}$ & $13.04 \mathrm{~b}^{\mathrm{ns}}$ & $9.46 b^{\mathrm{ns}}$ \\
\hline Jalapeño & $64.53 \mathrm{a}$ & $1.81 \mathrm{~b}$ & $88.06 a^{\text {ns }}$ & $42.0 \mathrm{a}^{*}$ & $72.02 \mathrm{a}^{\mathrm{ns}}$ & $30.96 b^{\mathrm{ns}}$ & $54.98 \mathrm{a}^{\text {ns }}$ & $28.88 \mathrm{~b}^{\mathrm{ns}}$ \\
\hline Biquinho vermelha & $97.55 \mathrm{a}$ & $45.54 \mathrm{a}$ & $61.06 a^{*}$ & $42.34 \mathrm{a}^{\mathrm{ns}}$ & $90.76 a^{\text {ns }}$ & $59.76 \mathrm{a}^{\mathrm{ns}}$ & $70.85 \mathrm{a}^{\mathrm{ns}}$ & $67.91 \mathrm{a}^{\mathrm{ns}}$ \\
\hline Tabasco & $31.24 \mathrm{~b}$ & $66.87 \mathrm{a}$ & $54.40 \mathrm{a}^{\mathrm{ns}}$ & $43.07 \mathrm{a}^{\mathrm{ns}}$ & $31.93 b^{\mathrm{ns}}$ & $18.92 b^{*}$ & $42.22 b^{\mathrm{ns}}$ & $20.23 b^{*}$ \\
\hline Stromboli & $49.39 b$ & $11.24 \mathrm{~b}$ & $43.24 \mathrm{~b}^{\mathrm{ns}}$ & $2.27 \mathrm{a}^{\mathrm{ns}}$ & $48.26 \mathrm{~b}^{\mathrm{ns}}$ & $0.86 \mathrm{~b}^{\mathrm{ns}}$ & $37.46 b^{\mathrm{ns}}$ & $2.10 \mathrm{~b}^{\mathrm{ns}}$ \\
\hline Malagueta & $17.20 \mathrm{c}$ & $17.80 \mathrm{~b}$ & $28.96 b^{\text {ns }}$ & $26.88 \mathrm{a}^{\mathrm{ns}}$ & $18.56 \mathrm{~b}^{\mathrm{ns}}$ & $30.75 b^{\mathrm{ns}}$ & $42.75 b^{\text {ns }}$ & $38.55 \mathrm{a}^{\mathrm{ns}}$ \\
\hline Rocoto vermelha & $39.10 \mathrm{~b}$ & $14.71 \mathrm{~b}$ & $61.04 a^{\text {ns }}$ & $13.33 \mathrm{a}^{\mathrm{ns}}$ & $71.45 \mathrm{a}^{*}$ & $45.59 \mathrm{a}^{\mathrm{ns}}$ & $83.39 \mathrm{a}^{*}$ & $50.0 \mathrm{a}^{*}$ \\
\hline
\end{tabular}

Source: Authors.

Compared with the control treatment $\left(0 \mathrm{mg} \mathrm{L}^{-1}\right), \mathrm{PBZ}$ at concentrations 5, 10 and $20 \mathrm{mg} \mathrm{L}^{-1}$ reduced the sensitivity to ethylene of the 'Pérola Negra' by 75, 65 and 59\%, respectively (Table 1). Similar effect was detected in the 'Biquinho Vermelha' treated with $5 \mathrm{mg} \mathrm{L}^{-1} \mathrm{PBZ}$, with a 37\% reduction in leaf abscission (Table 1 and Figure 1). The other cultivars did not show significant differences in terms of sensitivity to ethylene, when compared to the control, regardless of the treatment with PBZ applied (Table 1).

Plants treated with PBZ had greener leaves than the control untreated plants (visual observation). Probably exogenous ethylene reduced the chlorophyll content of the leaf (Figure 1). Araújo, Freire, Guimarães, Lima and Finger (2019) also observed these negative effects caused by ethylene in ornamental pepper plants Capsicum annиит, accession 'BGH 1039'. Therefore, in this study, PBZ was efficient in reducing chlorophyll degradation in leaves caused by ethylene. Most studies with PBZ are focused on the effects it causes on plant size, flowering and fruiting, as reported by França et al., (2017 and 2018) and Ribeiro et al., (2019b) in Capsicum spp. Whatever the positive effects that PBZ can provide to peppers, in terms of sensitivity to ethylene, it is extremely important to improve plant quality and increase shelf life. 
Figure 1 - Effect of ethylene action on cultivar 'Biquinho Vermelha', 48 hours after exposure to ethylene. A1 - Control plant (0 mg L-1 PBZ); A2 - $5 \mathrm{mg} \mathrm{L}^{-1}$ PBZ.

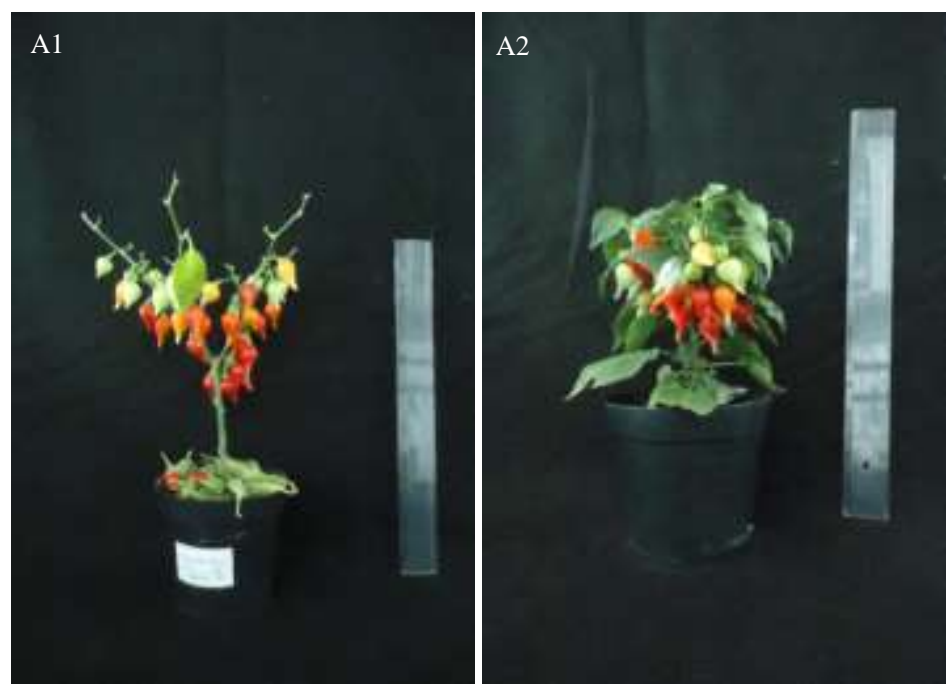

Source: Authors.

Fruit abscission in plants treated with $5 \mathrm{mg} \mathrm{L}^{-1} \mathrm{PBZ}$ had no formation of groups, all the cultivars showed less than $50 \%$ of fruit abscission (Table 1). At doses of 10 and $20 \mathrm{mg} \mathrm{L}^{-1} \mathrm{PBZ}$, the cultivars were divided into two distinct groups. 'Bode vermelha, 'Biquinho vermelha', 'Malagueta' and 'Rocoto vermelha' were the cultivars that presented the highest average

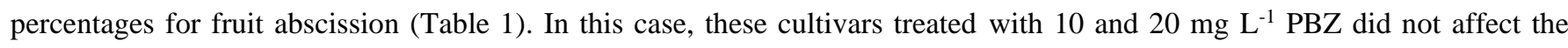
sensitivity to ethylene. Fruits are the main decoration elements of ornamental peppers, which attract the most attention of consumers at the time of purchase (Neitzke, Fischer, Vasconcelos, Barbieri \& Treptow, 2016). Therefore, it is necessary that, in addition to presenting an adequate size for ornamentation, the peppers have colored fruits, contrasting between foliage (Finger, Rêgo, Segatto, Nascimento \& Rêgo, 2012) the fruits must remain attached to the plant.

In Table 2, after 96 hours of the exposure to ethylene, cultivars treated with 5, 10 and $20 \mathrm{mg} \mathrm{L}^{-1} \mathrm{PBZ}_{\text {were divided }}$ into two distinct classes for leaf abscission. The cultivars 'Pérola Negra', 'Bode vermelha' and 'Peloteira' had the lowest average leaf abscission. Although they are more resistant to the harmful action of ethylene, the cultivars showed a high average leaf abscission (Table 2). However, when compared to the control treatment, leaf abscission was reduced by more than $50 \%$ in the 'Pérola Negra' when treated with 5, 10 and $20 \mathrm{mg} \mathrm{L}^{-1}$ PBZ (Table 2). On the other hand, the 'Peloteira' and 'Pirâmide Ornamental' had increased leaf abscission at concentrations of 5 and $20 \mathrm{mg} \mathrm{L}^{-1} \mathrm{PBZ}$ (Table 2).

The other cultivars treated with PBZ did not show significant effects when compared to the control treatment (Table 2). This divergence of results can be explained by the fact that the effects caused by PBZ on plants vary between species, varieties, concentration and form of application (Rademacher, 2000). França et al. (2018) and Ribeiro et al. (2019b) studying the effect of PBZ on Capsicum, obtained different responses among the varieties studied, when using different ways of treatment, concentrations and varieties of pepper. 
Table 2 - Means of eleven cultivars for leaf abscission (LA) and fruit abscission (FA) of pepper, 96 hours after exposure to ethylene, with application of 0,5, 10 and $20 \mathrm{mg} \mathrm{L-1}$ of PBZ. Equal letters in columns do not differ statistically by Scott-Knott criterion at $1 \%$ probability. * followed on the same line indicates significance by the Dunnett test at $5 \%$ probability.

\begin{tabular}{|c|c|c|c|c|c|c|c|c|}
\hline \multirow{3}{*}{ Cultivarss } & \multicolumn{8}{|c|}{96 hours } \\
\hline & \multicolumn{2}{|c|}{$0 \mathrm{mg} \mathrm{L}^{-1}$} & \multicolumn{2}{|c|}{$5 \mathrm{mg} \mathrm{L}^{-1}$} & \multicolumn{2}{|c|}{$10 \mathrm{mg} \mathrm{L}^{-1}$} & \multicolumn{2}{|c|}{$20 \mathrm{mg} \mathrm{L}^{-1}$} \\
\hline & LA & FA & LA & FA & LA & FA & LA & FA \\
\hline Pirâmide ornamental & $49.42 b$ & $59.61 \mathrm{a}$ & $57.10 \mathrm{~b}^{\mathrm{ns}}$ & $24.28 b^{*}$ & $70.63 \mathrm{a}^{\mathrm{ns}}$ & $24.44 b^{*}$ & $80.50 \mathrm{a}^{*}$ & $24.31 b^{*}$ \\
\hline Pérola negra & $84.03 \mathrm{a}$ & $35.99 b$ & $40.62 b^{*}$ & $5.83 b^{\mathrm{ns}}$ & $38.04 \mathrm{~b} *$ & $12.99 \mathrm{~b}^{\mathrm{ns}}$ & $42.09 \mathrm{~b} *$ & $35.30 b^{\mathrm{ns}}$ \\
\hline Dedo de moça & $76.82 \mathrm{a}$ & $42.51 \mathrm{a}$ & $57.48 \mathrm{~b}^{\mathrm{ns}}$ & $33.0 \mathrm{a}^{\mathrm{ns}}$ & $47.57 \mathrm{~b} *$ & $19.47 b^{\mathrm{ns}}$ & $65.75 \mathrm{a}^{\mathrm{ns}}$ & $11.19 b^{\mathrm{ns}}$ \\
\hline Bode vermelha & $53.90 \mathrm{~b}$ & $56.40 \mathrm{a}$ & $58.82 \mathrm{~b}^{\mathrm{ns}}$ & $50.52 \mathrm{a}^{\mathrm{ns}}$ & $43.19 b^{\mathrm{ns}}$ & $62.83 \mathrm{a}^{\mathrm{ns}}$ & $51.01 b^{\mathrm{ns}}$ & $61.14 \mathrm{a}^{\mathrm{ns}}$ \\
\hline Peloteira & $11.21 \mathrm{c}$ & $7.52 b$ & $44.95 \mathrm{~b} *$ & $31.58 \mathrm{a}^{\mathrm{ns}}$ & $38.13 b^{\mathrm{ns}}$ & $31.31 b^{\mathrm{ns}}$ & $22.67 b^{\mathrm{ns}}$ & $15.94 b^{\mathrm{ns}}$ \\
\hline Jalapeño & $79.04 \mathrm{a}$ & $23.66 \mathrm{~b}$ & $95.71 \mathrm{a}^{\mathrm{ns}}$ & $47.33 \mathrm{a}^{\mathrm{ns}}$ & $81.40 \mathrm{a}^{\mathrm{ns}}$ & $39.69 b^{\mathrm{ns}}$ & $77.72 \mathrm{a}^{\mathrm{ns}}$ & $46.11 \mathrm{a}^{\mathrm{ns}}$ \\
\hline Biquinho vermelha & $100 \mathrm{a}$ & $62.44 \mathrm{a}$ & $94.31 \mathrm{a}^{\mathrm{ns}}$ & $49.05 \mathrm{a}^{\mathrm{ns}}$ & $98.13 \mathrm{a}^{\mathrm{ns}}$ & $64.89 \mathrm{a}^{\mathrm{ns}}$ & $96.12 \mathrm{a}^{\mathrm{ns}}$ & $85.79 a^{n s}$ \\
\hline Tabasco & $70.86 a$ & $72.63 a$ & $81.79 \mathrm{a}^{\mathrm{ns}}$ & $49.90 \mathrm{a}^{\mathrm{ns}}$ & $73.23 \mathrm{a}^{\mathrm{ns}}$ & $26.93 b *$ & $77.40 \mathrm{a}^{\mathrm{ns}}$ & $33.09 b^{*}$ \\
\hline Stromboli & $77.93 \mathrm{a}$ & $19.75 b$ & $84.23 \mathrm{a}^{\mathrm{ns}}$ & $3.92 b^{\mathrm{ns}}$ & $80.65 \mathrm{a}^{\mathrm{ns}}$ & $5.70 b^{\mathrm{ns}}$ & $71.86 \mathrm{a}^{\mathrm{ns}}$ & $5.74 b^{\mathrm{ns}}$ \\
\hline Malagueta & $72.11 \mathrm{a}$ & $32.58 b$ & $92.42 \mathrm{a}^{\mathrm{ns}}$ & $39.89 a^{n s}$ & $85.59 \mathrm{a}^{\mathrm{ns}}$ & $37.55 b^{\mathrm{ns}}$ & $78.86 \mathrm{a}^{\mathrm{ns}}$ & $64.74 a^{n s}$ \\
\hline Rocoto vermelha & $88.47 \mathrm{a}$ & $14.71 b$ & $89.34 \mathrm{a}^{\mathrm{ns}}$ & $31.66 \mathrm{a}^{\mathrm{ns}}$ & $95.20 \mathrm{a}^{\mathrm{ns}}$ & $76.30 \mathrm{a}^{*}$ & $92.89 \mathrm{a}^{\mathrm{ns}}$ & $75.0 a^{*}$ \\
\hline
\end{tabular}

Source: Authors.

Regarding the abscission of fruits, the cultivars were divided into two distinct groups, when treated with 5, 10 or 20 mg L ${ }^{-1}$ PBZ (Table 2). The cultivars 'Pirâmide ornamental', 'Pérola negra' and 'Stromboli' stand out as the most resistant to fruit drop, with an average fruit abscission of less than $25 \%$ (Table 2).

Compared to the control treatment, the 'Pirâmide ornamental' and 'Tabasco' cultivars showed a decrease in fruit abscission when treated with 5,10 or $20 \mathrm{mg} \mathrm{L}^{-1}$ and 10 or $20 \mathrm{mg} \mathrm{L}^{-1} \mathrm{PBZ}$, respectively (Table 2). These results showed that PBZ is effective in reducing damage caused by exogenous ethylene in ornamental peppers. The damage caused by ethylene on fruit abscission depends on the period of exposure, concentration, temperature, the stage of fruit development and the sensitivity of species and varieties (Finger, Silva, Segatto \& Barbosa, 2015). Santos et al. (2013), Lima et al. (2017) and Ribeiro et al. (2019a), evaluating ornamental pepper genotypes for sensitivity to ethylene, reported that ethylene affected, in different degrees, the longevity of plants exposed to the hormone.

Most plants are sensitive to ethylene after being exposed to 0.5 to $1.0 \mu \mathrm{L} \mathrm{L}^{-1}$ (Abeles, Morgan \& Sampaio, 1992; Iqbal et al., 2017). Generally, there is $50 \%$ response between $0.1-1.0 \mu \mathrm{L} \mathrm{L}^{-1}$ and saturation between 1.0 and $10 \mu \mathrm{L} \mathrm{L}-1$ of ethylene. Based on this classification, varieties or organs are classified as sensitive or insensitive to exogenous ethylene. Thus, plants that do not respond to $10 \mu \mathrm{L} \mathrm{L}^{-1}$ of ethylene can be considered insensitive. According to Iqbal et al. (2017), different species, varieties and organs of Capsicum have particular sensitivity levels for each, therefore, different response intensities. This may be related to the amount of ethylene receptors in different organs. Furthermore, the effect of ethylene may be independent or dependent on its interaction with other hormones.

In Table 3, 144 hours after exposure to ethylene, leaf abscission showed different sensitivity levels, being the cultivars grouped into three distinct classes for the 5 and $20 \mathrm{mg} \mathrm{L}^{-1} \mathrm{PBZ}$ and two classes for the $10 \mathrm{mg} \mathrm{L}^{-1} \mathrm{PBZ}$ (Table 3). When compared to the control plants, the 'Pérola negra' cultivar showed a decrease in leaf abscission by $46 \%$, $46 \%$ and $42 \%$, when treated with 5, 10 or $20 \mathrm{mg} \mathrm{L}^{-1} \mathrm{PBZ}$, respectively (Table 3 and Figure 2). 
Table 3 - Means of eleven cultivars for leaf abscission (LA) and fruit abscission (FA) of pepper, 144 hours after exposure to ethylene, with application of $0,5,10$ and $20 \mathrm{mg} \mathrm{L}^{-1}$ of PBZ. Equal letters in columns do not differ statistically by Scott-Knott criterion at $1 \%$ probability. $*$ followed on the same line indicates significance by the Dunnett test at $5 \%$ probability.

\begin{tabular}{|c|c|c|c|c|c|c|c|c|}
\hline \multirow{3}{*}{ Cultivars } & \multicolumn{8}{|c|}{144 hours } \\
\hline & \multicolumn{2}{|c|}{$0 \mathrm{mg} \mathrm{L}^{-1}$} & \multicolumn{2}{|c|}{$5 \mathrm{mg} \mathrm{L}^{-1}$} & \multicolumn{2}{|c|}{$10 \mathrm{mg} \mathrm{L}^{-1}$} & \multicolumn{2}{|c|}{$20 \mathrm{mg} \mathrm{L}^{-1}$} \\
\hline & LA & FA & LA & FA & LA & FA & LA & FA \\
\hline Pirâmide ornamental & $66.85 b$ & $62.0 \mathrm{a}$ & $75.52 b^{\mathrm{ns}}$ & $26.51 b^{*}$ & $90.10 a^{*}$ & $24.44 b^{*}$ & $89.81 \mathrm{a}^{\mathrm{ns}}$ & $33.27 b^{\mathrm{ns}}$ \\
\hline Pérola negra & $93.16 \mathrm{a}$ & $49.22 \mathrm{a}$ & $50.13 c^{*}$ & $9.71 b^{*}$ & $50.19 b^{*}$ & $14.52 b^{*}$ & $53.70 b^{*}$ & $38.70 \mathrm{~b}^{\mathrm{ns}}$ \\
\hline Dedo de moça & $94.16 \mathrm{a}$ & $49.19 \mathrm{a}$ & $72.70 \mathrm{~b}^{\mathrm{ns}}$ & $33.0 b^{\mathrm{ns}}$ & $74.52 \mathrm{a}^{\mathrm{ns}}$ & $23.23 b^{\mathrm{ns}}$ & $89.66 a^{\text {ns }}$ & $18.04 b^{\text {ns }}$ \\
\hline Bode vermelha & $61.35 \mathrm{~b}$ & $58.44 a$ & $69.29 b^{*}$ & $58.18 \mathrm{a}^{\mathrm{ns}}$ & $56.90 b^{*}$ & $71.72 \mathrm{a}^{\mathrm{ns}}$ & $63.59 b^{*}$ & $63.40 \mathrm{a}^{\mathrm{ns}}$ \\
\hline Peloteira & $19.44 \mathrm{c}$ & $9.12 b$ & $50.65 c^{*}$ & $40.47 \mathrm{a}^{\mathrm{ns}}$ & $47.97 b^{*}$ & $32.98 b^{n s}$ & $29.62 c^{n s}$ & $20.90 b^{\mathrm{ns}}$ \\
\hline Jalapeño & $90.67 \mathrm{a}$ & $30.60 \mathrm{~b}$ & $95.83 \mathrm{a}^{\mathrm{ns}}$ & $51.33 \mathrm{a}^{\mathrm{ns}}$ & $88.19 \mathrm{a}^{\mathrm{ns}}$ & $42.19 b^{n s}$ & $86.77 \mathrm{a}^{\mathrm{ns}}$ & $46.11 b^{\mathrm{ns}}$ \\
\hline Biquinho vermelha & $100 \mathrm{a}$ & $62.86 \mathrm{a}$ & $98.81 \mathrm{a}^{\mathrm{ns}}$ & $51.63 \mathrm{a}^{\mathrm{ns}}$ & $99.79 \mathrm{a}^{\mathrm{ns}}$ & $66.94 \mathrm{a}^{\mathrm{ns}}$ & $100 \mathrm{a}^{\mathrm{ns}}$ & $92.46 \mathrm{a}^{\mathrm{ns}}$ \\
\hline Tabasco & $74.33 b$ & $74.26 \mathrm{a}$ & $89.42 \mathrm{a}^{\mathrm{ns}}$ & $54.52 \mathrm{a}^{\mathrm{ns}}$ & $84.03 \mathrm{a}^{\mathrm{ns}}$ & $26.93 b^{*}$ & $87.58 \mathrm{a}^{\mathrm{ns}}$ & $40.53 b^{n s}$ \\
\hline Stromboli & $91.40 \mathrm{a}$ & $23.55 b$ & $91.60 \mathrm{a}^{\mathrm{ns}}$ & $9.31 b^{\mathrm{ns}}$ & $91.90 \mathrm{a}^{\mathrm{ns}}$ & $10.95 b^{\mathrm{ns}}$ & $84.84 \mathrm{a}^{\mathrm{ns}}$ & $6.30 \mathrm{~b}^{\mathrm{ns}}$ \\
\hline Malagueta & $84.06 \mathrm{a}$ & $34.69 \mathrm{~b}$ & $96.58 \mathrm{a}^{\mathrm{ns}}$ & $44.97 \mathrm{a}^{\mathrm{ns}}$ & $94.15 \mathrm{a}^{\mathrm{ns}}$ & $44.36 b^{\mathrm{ns}}$ & $92.57 \mathrm{a}^{\mathrm{ns}}$ & $66.66 \mathrm{a}^{\mathrm{ns}}$ \\
\hline Rocoto vermelha & $92.73 \mathrm{a}$ & $36.38 \mathrm{~b}$ & $96.05 \mathrm{a}^{\mathrm{ns}}$ & $58.33 \mathrm{a}^{\mathrm{ns}}$ & $98.86 \mathrm{a}^{\mathrm{ns}}$ & $76.30 a^{*}$ & $96.47 \mathrm{a}^{\mathrm{ns}}$ & $81.66 a^{*}$ \\
\hline
\end{tabular}

Source: Authors.

Figure 2 - Effect of ethylene action, 144 hours after exposure, on cultivar 'Pérola'. A1 - Control treatment (0 mg L-1 PBZ); A2 - 5 mg L ${ }^{-1}$ PBZ; A3 - 10 mg L-1 PBZ; A4 - 20 mg L-1 PBZ.
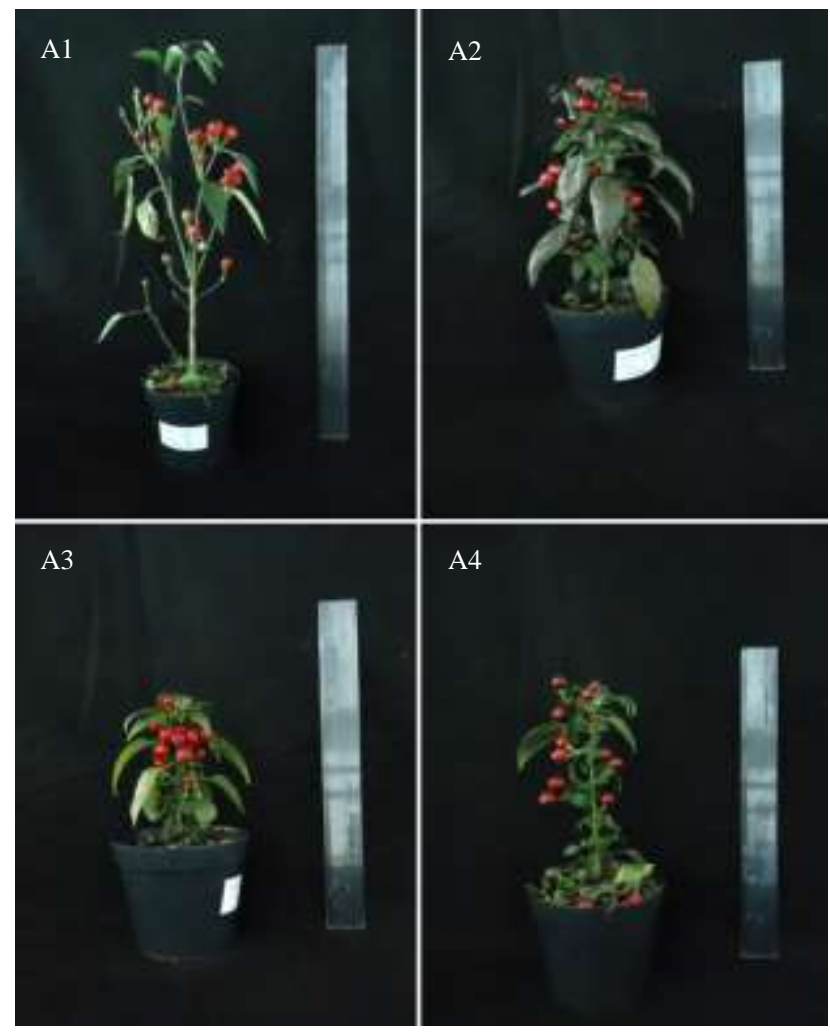

Source: Authors. 
Regarding the abscission of the fruits, cultivars were divided into two distinct classes when treated with 5, 10 or 20 mg L ${ }^{-1}$ PBZ. Cultivars 'Pirâmide ornamental', 'Pérola negra', 'Dedo de Moça', 'Peloteira', 'Jalapeño', 'Tabasco' and 'Stromboli' are more resistant to the harmful action of ethylene (Table 3). On the other hand, the application of PBZ at concentrations 10 and $20 \mathrm{mg} \mathrm{L}^{-1}$ increased the percentage of fruit abscission 'Rocoto vermelha'. When compared to the control treatment, the cultivars 'Pirâmide ornamental' and 'Pérola negra' showed resistance to ethylene, with a reduction in fruit abscission varying between $57 \%$ and $80 \%$, when treated with 5 and $10 \mathrm{mg} \mathrm{L}^{-1}$ PBZ (Table 3 and Figure 3). Furthermore, the leaves of plants treated with PBZ did not show yellowing (visual observation, Figure 3), possibly the PBZ prevented the degradation of chlorophyll by exogenous ethylene.

Figure 3 - Effect of ethylene action, 144 hours after exposure, on cultivar 'Pirâmide Ornamental'. A1 - Control treatment (0 mg L-1 PBZ); A2 - 5 mg L ${ }^{-1}$ PBZ; A3 - 10 mg L-1 PBZ; A4 - 20 mg L-1 PBZ.
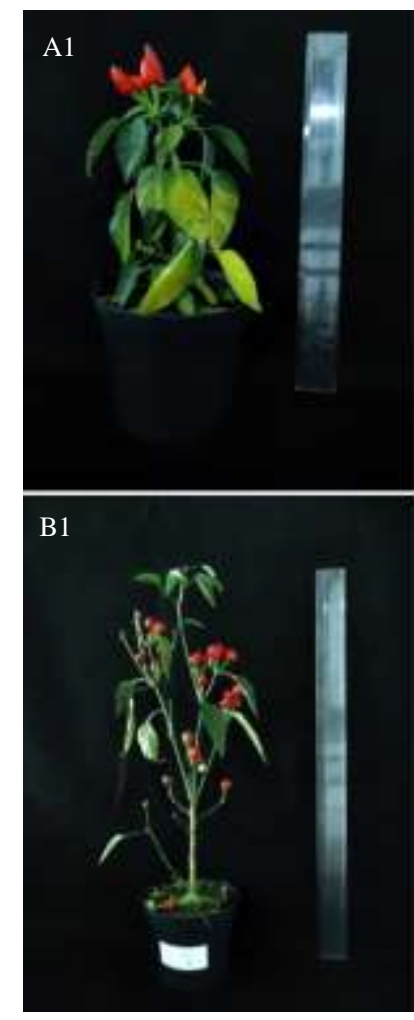
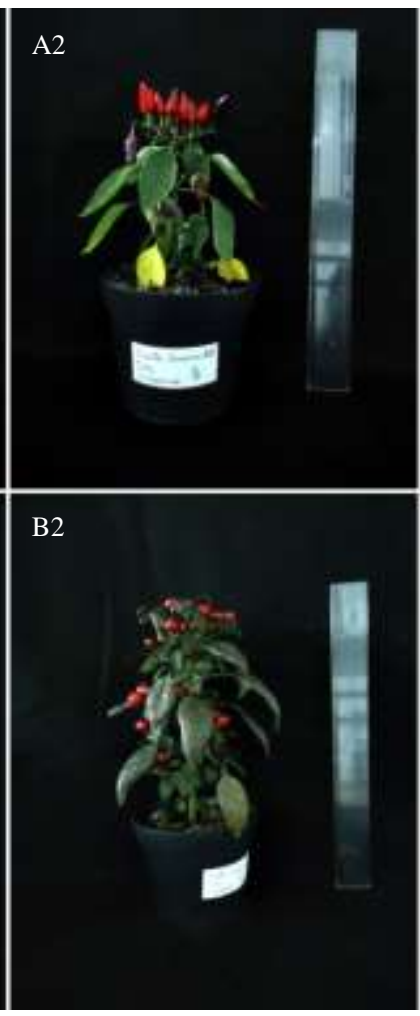

Source: Authors.
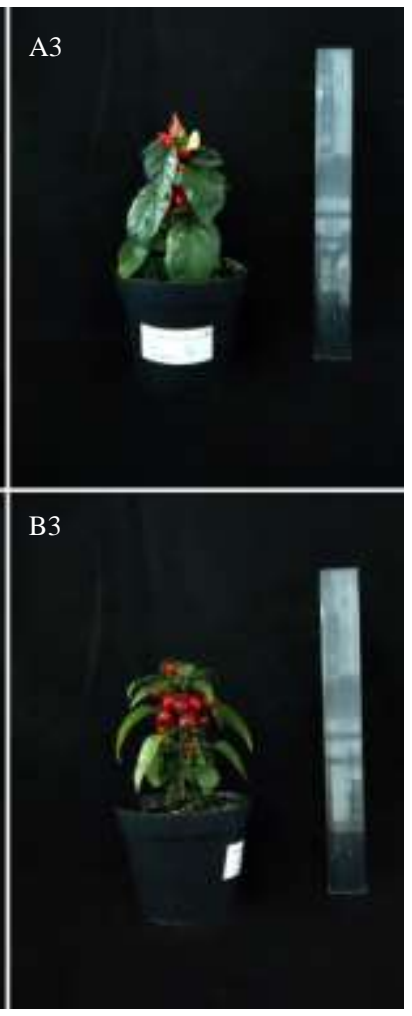


\section{Final Considerations}

The use of PBZ did not completely prevent the deleterious effects of exogenous ethylene on the plants. The 'Pérola negra' cultivar showed moderate sensitivity to leaf and fruit abscission. Likewise, just for leaf abscission, 'Bode vermelha' treated with $10 \mathrm{mg} \mathrm{L}^{-1}$. The PBZ moderately prevented the abscission of fruits of the 'Pirâmide ornamental' at doses 5 and 10 $\mathrm{mg} \mathrm{L}$ ', and of 'Tabasco' pepper at a concentration of $10 \mathrm{mg} \mathrm{L}^{-1}$.

In future work, higher doses of PBZ and its application via foliar spray could bring more effective results in order to avoid the deleterious effects of ethylene on peppers. In addition, it could provide more suitable characteristics for ornamental pepper plants.

\section{Acknowledgments}

The authors are grateful for the financial support by CNPq (National Council for Scientific and Technological Development) and CAPES (Coordination for the Improvement of Higher Education Personnel).

\section{References}

Abeles, F., Morgan, P. W., \& Saltveit Júnior, M. E. (1992). Ethylene in plant biology. (2nd ed). San Diego: Academic Press.

Ahmad, I., Dole, J. M., \& Whipker, B. E. (2015). Paclobutrazol or uniconazole effects on ethylene sensitivity of pottedornamental plants and plugs. Scientia Horticulturae, 192, 350-356.

Antunes, A. M., Ono, E. O., \& Sampaio, A. C. (2008). Efeito do paclobutrazol no controle da diferenciação floral natural do abacaxizeiro cv. smooth cayenne. Revista Brasileira de Fruticultura, 30(2), 90-295.

Araujo, F. F., Freire, A. I., Guimarães, M. E. S., Lima, P. C. C., \& Finger, F. L. (2019). Influence of 1-methylcyclopropene on the longevity of potted ornamental peppers, Revista Brasileira de Ciências Agrárias, 14(1), 1- 7.

Bosland, P. W. (1999). Encyclopedia of chiles. In: Hanson, B. (Coord.), Chile peppers, Brooklyn Botanical Garden - Brooklyn Botanical Garden (p. 17-21), Brooklyn - NY.

Chen, Y. F., Etheridge, N., \& Schaller, E. (2005). Ethylene signal perception. Annals of Botany, 95, 901-915.

Costa, M. P. S. D., Rêgo, E. R., Guedes, J. F. S., Carvalho, M. G., Silva, A. R., \& Rêgo, M. M. (2021). Selection of genotypes with ornamental potential in an $\mathrm{F}_{4}$ population of ornamental peppers (Capsicum annuum L.) based on multivariate analysis. Comunicata Scientiae, 12, e3511, 1-8.

Cruz, C. D. (2013). Genes: a software package for analysis in experimental statistics and quantitative genetics. Acta Scientiarum, 35(3), 271-276.

Finger, F. L., Rêgo, E. R., Segatto, F. B., Nascimento, N. F. F., \& Rêgo, M. M. (2012). Produção e potencial de mercado para pimenta ornamental. Informe Agropecuário, 33, 14-20.

Finger, F. L., Silva, T. P., Segatto, F. B., \& Barbosa, J. G. (2015). Inhibition of ethylene response by 1-methylcyclopropene in potted ornamental pepper. Ciência Rural, 45(6), 964-969.

Finger, F. L., \& Pereira, G. M. (2016). Physiology and Postharvest od pepper fruits. In: Rêgo, E. R., Rêgo, M. M., \& Finger, F. L. (Coord), Production and breending of chilli peppers (Capsicum spp) - Springer (p. 27-40), New York - USA.

França, C. F. M., Costa, L. C., Ribeiro, W. S., Mendes, T. D. C., Santos, M. N. S., \& Finger, F. L. (2017). Evaluation of paclobutrazol application method on quality characteristics of ornamental pepper. Ornamental Horticulture, 23(3), 307-310.

França, C. F. M., Ribeiro, W. S., Santos, M. N. S., Petrucci, K. P. O. S., Rêgo, E. R., \& Finger, F. L. (2018). Growth and quality of potted ornamental peppers treated with paclobutrazol. Pesquisa Agropecuária Brasileira, 53, 316-322.

Iqbal, N., Khan, N. A., Ferrante, A., Trivellini, A., Francini, A., \& Khan, M. (2017). Ethylene role in plant growth, development and senescence: interaction with other phytohormones. Frontiers in Plant Science, 8, e475, 1-19.

Leatherwood, R., \& Mattson, N. S. (2010). Cornell research update ethylene in the greenhouse: symptoms of short and long term exposure. Indiana Flower Grow, 4 (1), 4-8.

Lima, P. C. C., Ribeiro, W. S., Oliveira, M. M. T., Costa, L. C., \& Finger, F. L. (2017). Ethylene, 1-methylcyclopropene and silver thiosulfate on the postproduction of ornamental pepper. Ciência Rural, 47(2), 1-8.

Mahmoud, A. M., \& El-Eslamboly, A. A. S. A. (2015). Production and evaluation of high yieldingsweet pepper hybrids undergreenhouse conditions. American-Eurasian Journal of Agricultural \& Environmental Sciences, 15, 573-580. 
Min, X. J., \& Bartholomew, D. P. (1996). Effect of plant growth regulators on ethylene production, 1- aminocyclopropane-1-carboxilic acid oxidase activity, and initiation of inflorescence development of pineapple. Journal of Plant Growth Regulation, 15(3), 121-128.

Nascimento, M. F., Santos, R. M. C., Araújo, F. F., Silva Neto, J. J., Finger, F. L., \& Bruckner, C. H. (2018). Sensitivity of potted ornamental peppers to ethylene. Ornamental Horticulture, 24(4), 429-434.

Neitzke, R. S., Fischer, S. Z., Vasconcelos, C. S., Barbieri, R. L., \& Treptow, R. O. (2016). Ornamental peppers: acceptance and preferences by consumers. Horticultura Brasileira, 34: 102-109.

Pinto, C. M. F., Santos, I. C., Araujo, F. F., \& Silva, T. P. (2016). Pepper importance and growth (Capsicum spp.) In: Rêgo, E. R., Rêgo, M. M., \& Finger, F. L (Coord), Production and breending of chilli peppers (Capsicum spp) - Springer (p. 1-25), New York - USA.

Rademacher, W. (2000). Growth retardants: effects on Gibberellin biosynthesis and other metabolic pathways. Annual Review of Plant Physiology and Molecular Biology, 51, 501-531.

Rebouças, T. N. H., Valverde, R. M. V., \& Teixeira, H. L. (2013). Bromatologia da pimenta malagueta in natura e processada em conserva. Horticultura Brasileira, 31, 163-165.

Rêgo, E. R., Rêgo, M. M., \& Barroso, P. A. (2016). Tissue culture of Capsicum spp. In: Rêgo ER, Rêgo MM, Finger FL (Coord.) Production and breeding of chilli peppers (Capsicum spp.) - Springer (p. 97-127), Cham.

Rêgo, E. R., \& Rêgo, M. M. (2016). Genetics and Breeding of Chili Pepper Capsicum spp. In: Rêgo, E. R., Rêgo, M. M., Finger, F.L. (Coord.). Production and Breeding of Chilli Peppers (Capsicum spp.) - Springer (p. 97-129), Nova York - USA.

Rêgo, E. R. \& Rêgo, M. M. (2018) Ornamental Pepper. In: Van Huylenbroeck J (Coord.) Ornamental Crops. Springer International Publishing (p. 529 - 565), Cham.

Ribeiro, W. S., Carneiro, C. S., França, C. F. M., Pinto, C. M. F., Lima, P. C. C., Finger, F. L., \& Costa, F. B. (2019a). Sensitivity of ornamental pepper to ethylene. Horticultura Brasileira, 37, 458-463.

Ribeiro, W. S., Carneiro, C. S., França, C. F. M., Pinto, C. M. F., Lima, P. C. C., Finger, F. L., \& Costa, F. B. (2019b). Paclobutrazol application in potted ornamental pepper. Horticultura Brasileira, 37, 464-468.

Santos, R. M. C., Nascimento, N. F. F., Rêgo, E. R., Nascimento, M. F., Borém, A., Finger, F. L., \& Costa, D. S. (2013). Ethylene resistance in a F2 population of ornamental Chili Pepper (Capsicum annuum). Acta Horticulturae, 1000, 433-438.

Segatto, F. B., Finger, F. L., Barbosa, J. G., Rêgo, E. R., \& Pinto, C. M. F. (2013). Effects of ethylene on the post-production of potted ornamental peppers (Capsicum annuиm L.). Acta Horticulturae, 1000, 217-222.

Stommel, J. R., \& Bosland, P. W. (2006). Ornamental pepper, Capsicum annuum. In: Anderson N (Coord.) Flower breeding and genetics: issues, challenges and opportunities for the 21 st century - Springer (pp 561-599), Dordrecht.

Xin, T., Zhang, Z., LI, S., Zhang, S., LI, Q., Zhang, Z. H., Huang, S., \& Yang, X. (2019). Genetic regulation of ethylene dosage for cucumber fruit elongation. Plant Cell, 31, 1063-1076. 